OAK RIDGE

National Laboratory

ORNL/TM-2002/147

MANAGED BY UT-BATTELLE

FOR THE DEPARTMENT OF ENERGY

\title{
Eberline Alpha 7L Test Report
}

P. J. Chiaro, Jr.

F. R. Gibson

A. A. Shourbaji

J. E. Dixon

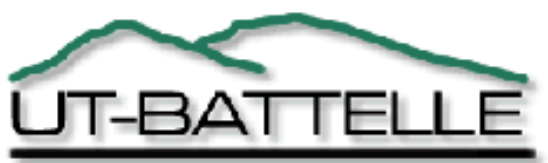




\title{
DOCUMENT AVAILABILITY
}

Reports produced after January 1, 1996, are generally available free via the U.S. Department of Energy (DOE) Information Bridge:

Web site: http://www.osti.gov/bridge

Reports produced before January 1, 1996, may be purchased by members of the public from the following source:

\author{
National Technical Information Service \\ 5285 Port Royal Road \\ Springfield, VA 22161 \\ Telephone: 703-605-6000 (1-800-553-6847) \\ TDD: 703-487-4639 \\ Fax: 703-605-6900 \\ E-mail: info@ntis.fedworld.gov \\ Web site: http://www.ntis.gov/support/ordernowabout.htm
}

Reports are available to DOE employees, DOE contractors, Energy Technology Data Exchange (ETDE) representatives, and International Nuclear Information System (INIS) representatives from the following source:

Office of Scientific and Technical Information

P.O. Box 62

Oak Ridge, TN 37831

Telephone: 865-576-8401

Fax: 865-576-5728

E-mail: reports@adonis.osti.gov

Web site: http://www.osti.gov/contact.html

This report was prepared as an account of work sponsored by an agency of the United States Government. Neither the United States government nor any agency thereof, nor any of their employees, makes any warranty, express or implied, or assumes any legal liability or responsibility for the accuracy, completeness, or usefulness of any information, apparatus, product, or process disclosed, or represents that its use would not infringe privately owned rights. Reference herein to any specific commercial product, process, or service by trade name, trademark, manufacturer, or otherwise, does not necessarily constitute or imply its endorsement, recommendation, or favoring by the United States Government or any agency thereof. The views and opinions of authors expressed herein do not necessarily state or reflect those of the United States Government or any agency thereof. 


\title{
Eberline Alpha 7L Test Report
}

\author{
Peter Chiaro, Jr., Fred Gibson, Ayman Shourbaji, John Dixon
}

July 2002

\author{
Prepared by \\ OAK RIDGE NATIONAL LABORATORY \\ P. O. Box 2008 \\ Oak Ridge, Tennessee 37831-6285 \\ Managed by \\ UT-Battelle, LLC \\ for the \\ U.S. DEPARTMENT OF ENERGY \\ under contract DE-AC05-00OR22725
}




\section{CONTENTS}

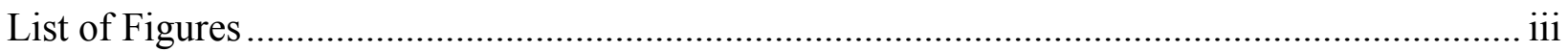

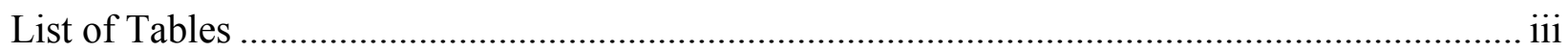

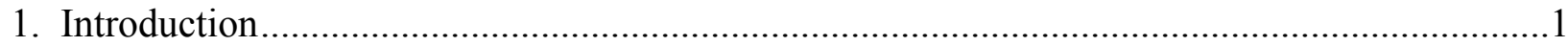

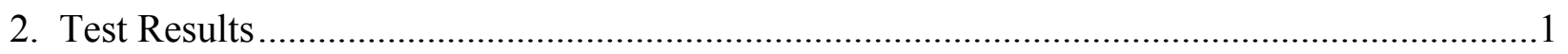

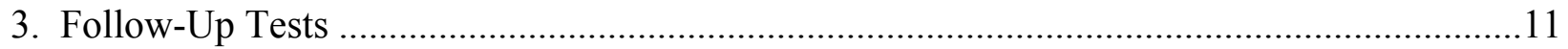

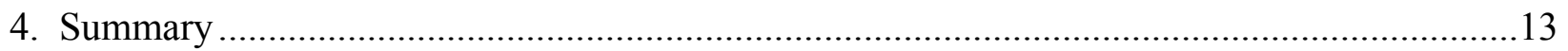




\section{LIST OF FIGURES}

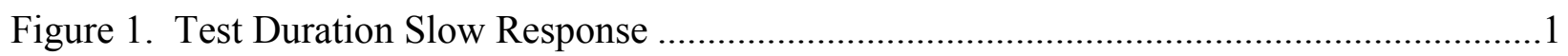

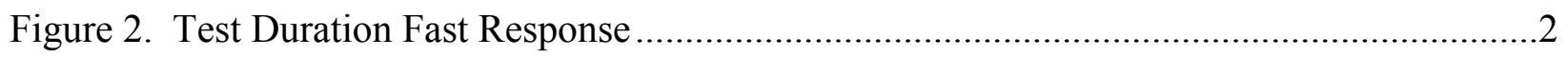

Figure 3. Temperature Test Results - Fast Response ..............................................................

Figure 4. Temperature Test Results - Slow Response ...............................................................

Figure 5. 10 Minute Readings - Fast Response.....................................................................

Figure 6. 10 Minute Readings - Slow Response ………........................................................

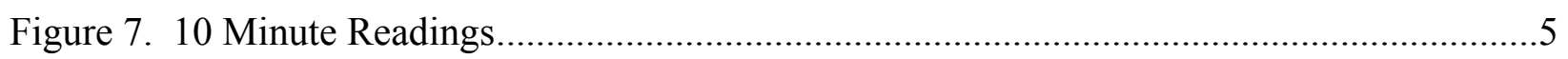

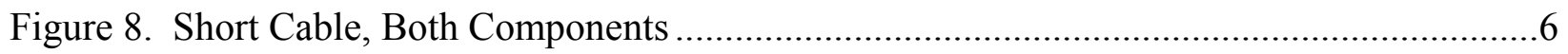

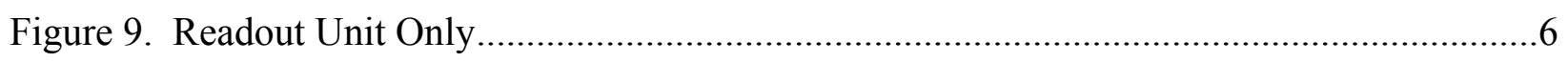

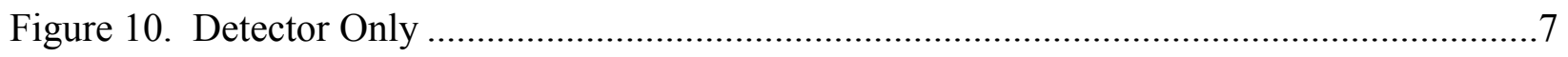

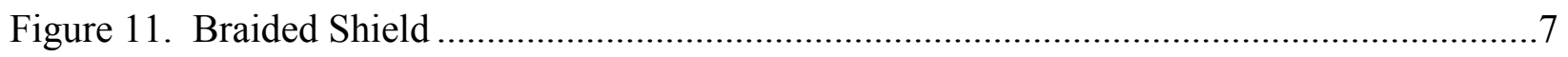

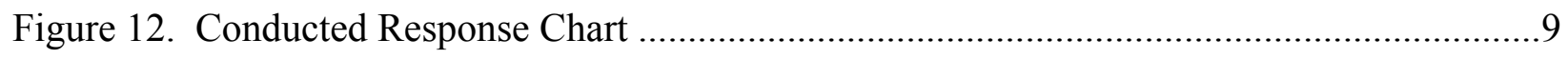

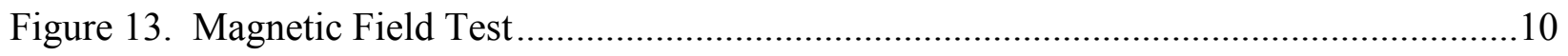

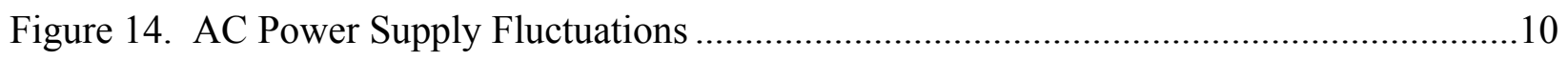

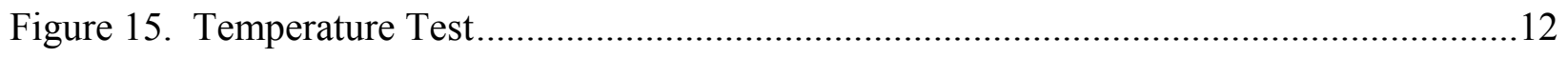

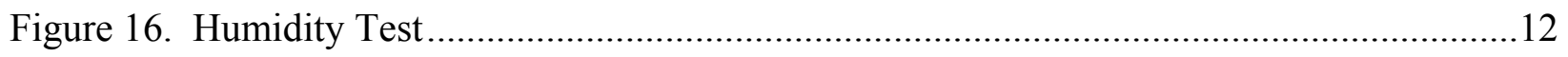

\section{LIST OF TABLES}

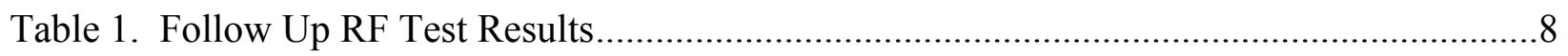

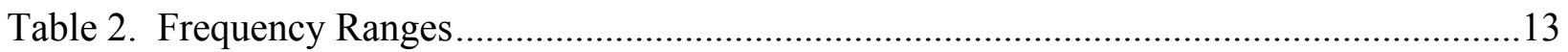




\section{EBERLINE ALPHA 7L TEST REPORT}

\section{INTRODUCTION}

An Eberline continuous alpha air monitor model Alpha 7L was evaluated at Oak Ridge National Laboratory (ORNL) using the capabilities available at the Environmental Effects Laboratory (EELab). A series of tests were performed to ensure that procured units meet the requirements of the purchasing facility, Los Alamos National Laboratory (LANL). In addition to reporting on the results of each test, other activities were performed to reduce discovered susceptibilities.

The parameters monitored during the tests typically included the airflow rate and/or net ${ }^{239} \mathrm{Pu}$ concentration values ( $\mathrm{pCi} /$ liter). In addition, the spectrum display and operational status were monitored. Follow up tests were also performed on two LANL-provided production units. The results of those tests are at the end of this report.

\section{TEST RESULTS}

\section{Temperature}

Test Parameters - Exposure to -20 to $+50^{\circ} \mathrm{C}$.

Results

No obvious susceptibilities were indicated from an initial review of the test results. We did notice that during the test, the unit became slightly erratic for about 4 hours. Scott Rogers of Eberline stated that this was expected. He explained that the operating program is set up such that after the unit collects 8000 counts it uses additional coefficients in the curve-fitting algorithm to obtain a more precise curve fit. No responses were over an alarm point.

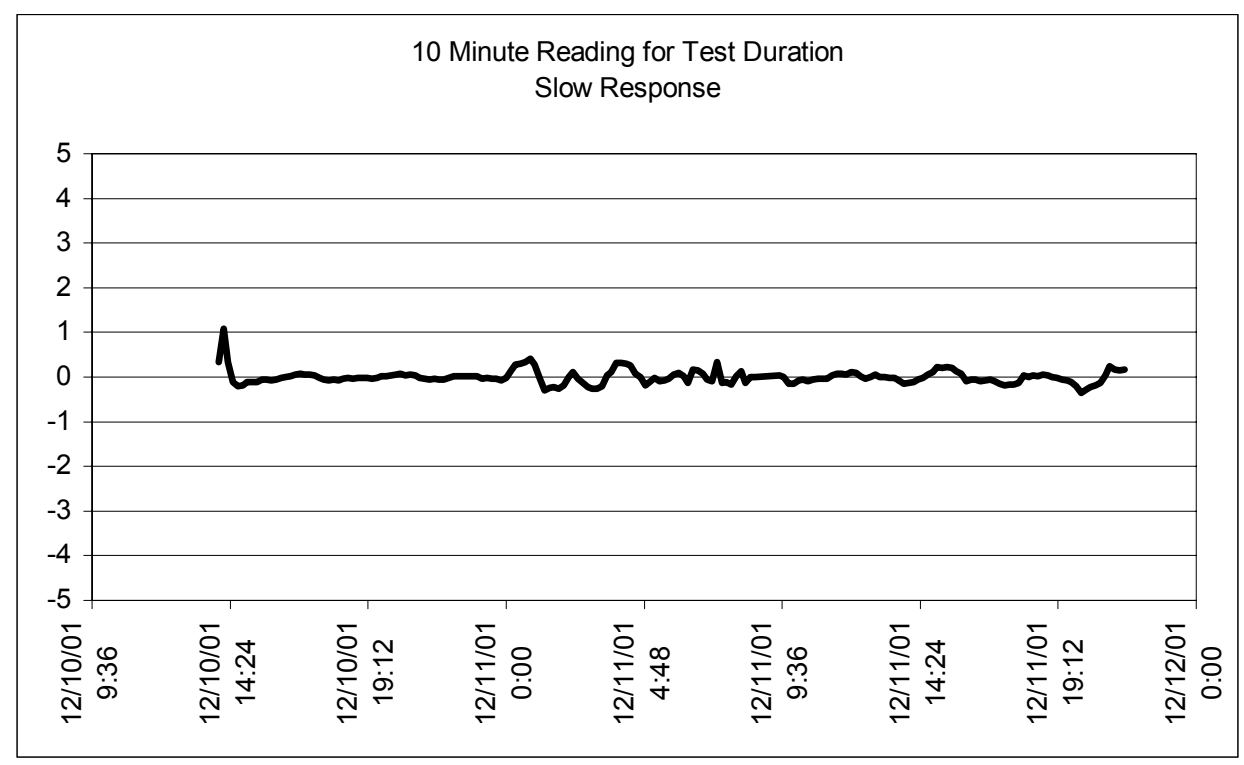

Figure 1. Test Duration Slow Response 
Figure 1 shows "slow" response data obtained at 10-minute intervals over the entire temperature test range of -20 to $+50{ }^{\circ} \mathrm{C}$. The change in variability of response is apparent and doesn't appear to be related to temperature as stated by Eberline.

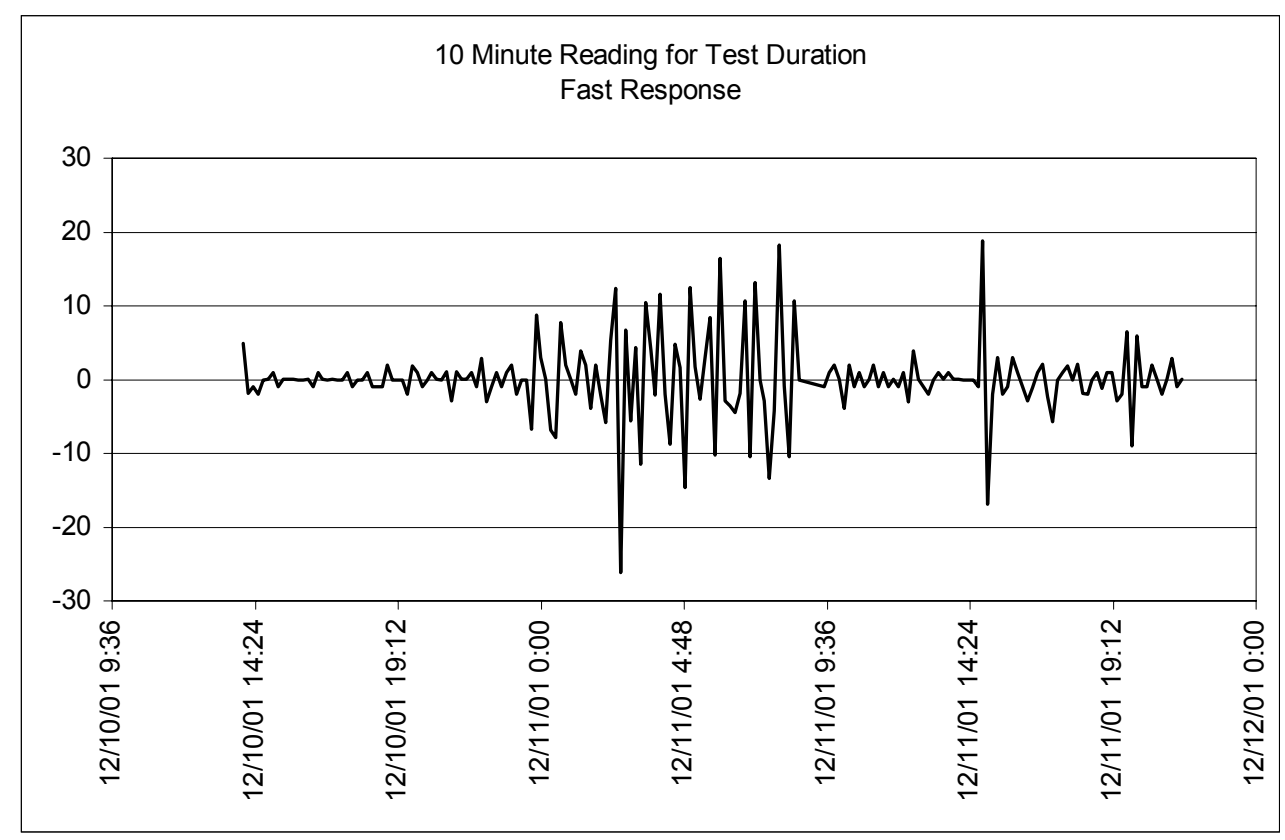

Figure 2. Test Duration Fast Response

Figure 2 contains "fast" response data taken at 10-minute intervals over the entire temperature test range. The change in variation is more obvious when compared to the "slow" results.

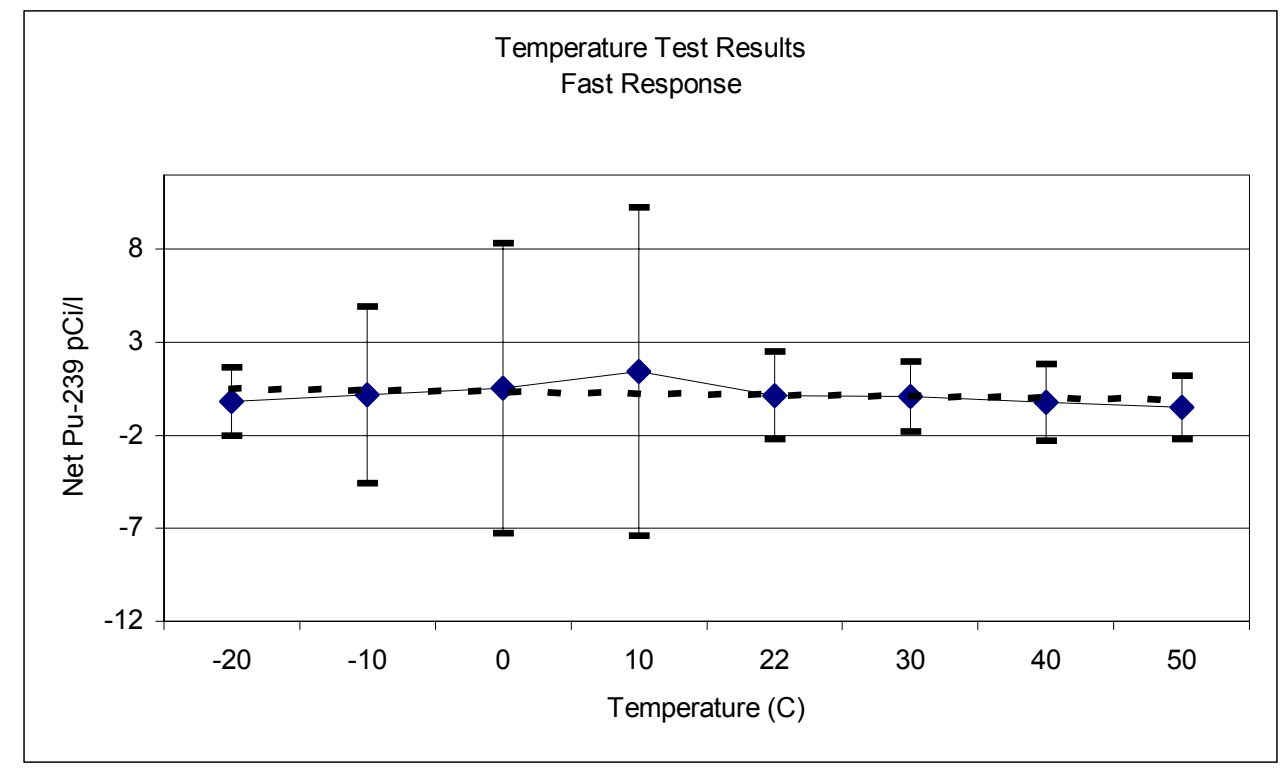

Figure 3. Temperature Test Results - Fast Response 
Figures 3 and 4 show the error bars associated with each average response at the temperature set point. Note the $y$-scale when comparing the fast response to the slow response (Figure 4).

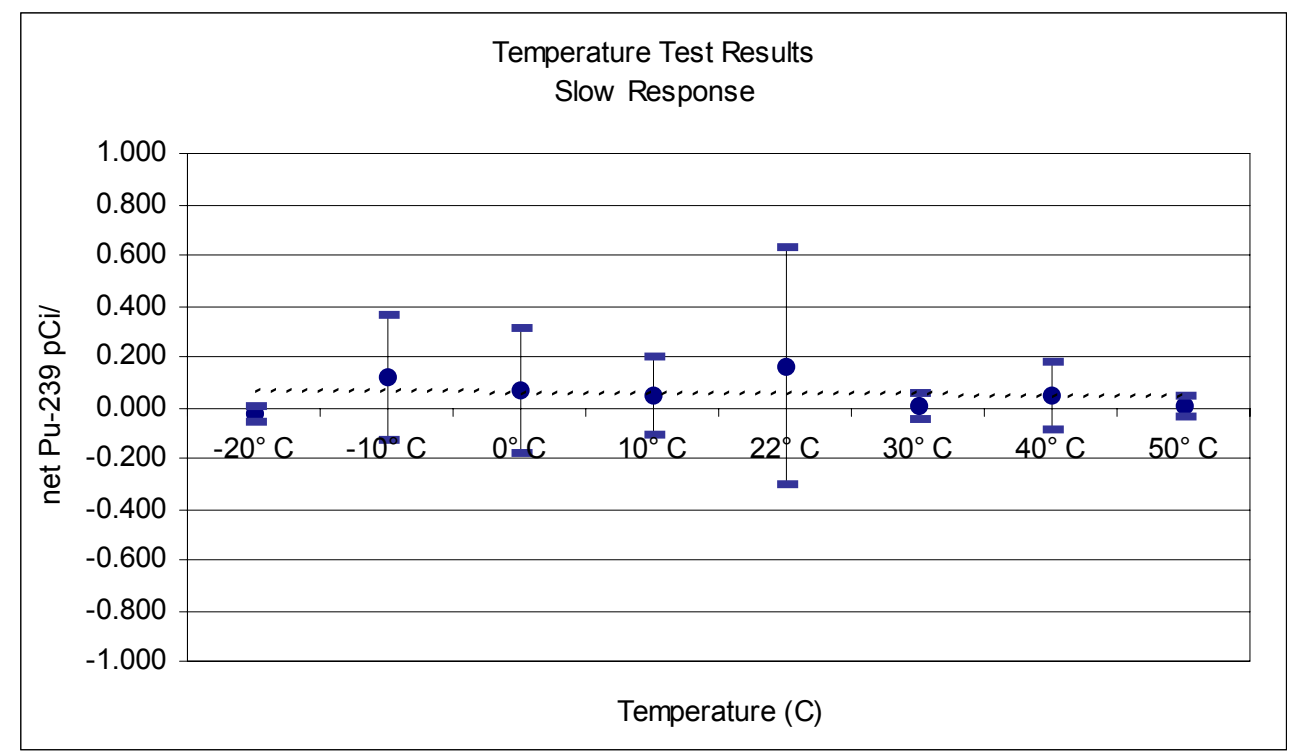

Figure 4. Temperature Test Results - Slow Response

No susceptibilities of any consequence were observed during the test. The observed variations in response were expected due to the techniques used to determine the fast response value.

Humidity

Test Parameters - Exposure to $40 \%$ to $95 \%$ relative humidity (non-condensing) at a temperature of $35^{\circ} \mathrm{C}$ $\pm 2^{\circ} \mathrm{C}$

Results

No obvious susceptibilities were indicated from an initial review of the test results. We did notice that the unit became somewhat erratic at 95\% humidity and eventually settled (about an hour). Excursions were observed to about 2 DAC (alarm point is 8 DAC-hrs). No responses were over an alarm point. Humidity did appear to load the filter somewhat, which affected the flow rate. It should be noted though that the filter used for this test was the same as that used for the temperature test since the humidity test is performed without stopping after the temperature test. 


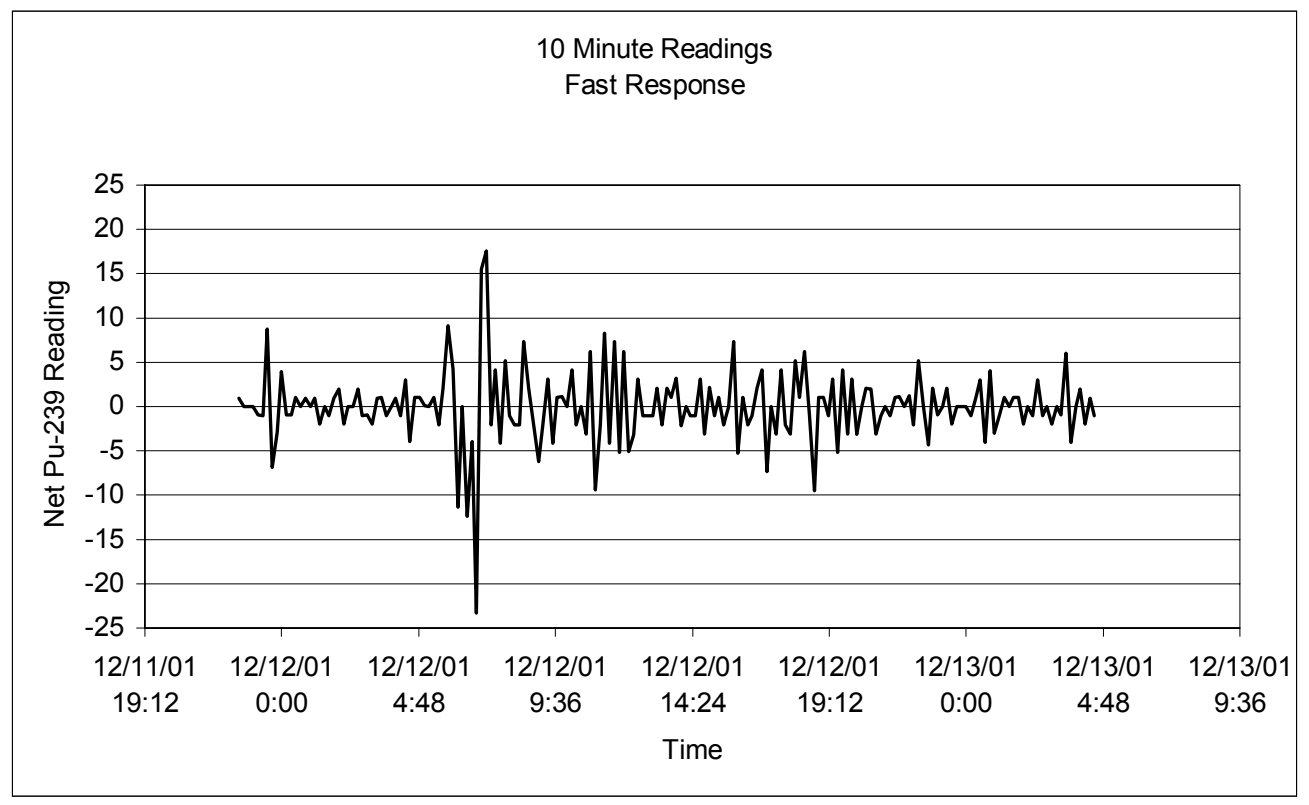

Figure 5. 10 Minute Readings - Fast Response

Figures 5 and 6 contain 10-minute response data (fast and slow, respectively) for the entire test from $40 \%$ to $95 \%$ and back to $40 \% \mathrm{RH}$ at a temperature of $35^{\circ} \mathrm{C}$. The $95 \%$ exposure lasted 16 hours and the initial and final $40 \%$ exposures were for four hours each. Other than the change in variability at the initial $95 \%$ exposure, not other susceptibilities were indicated.

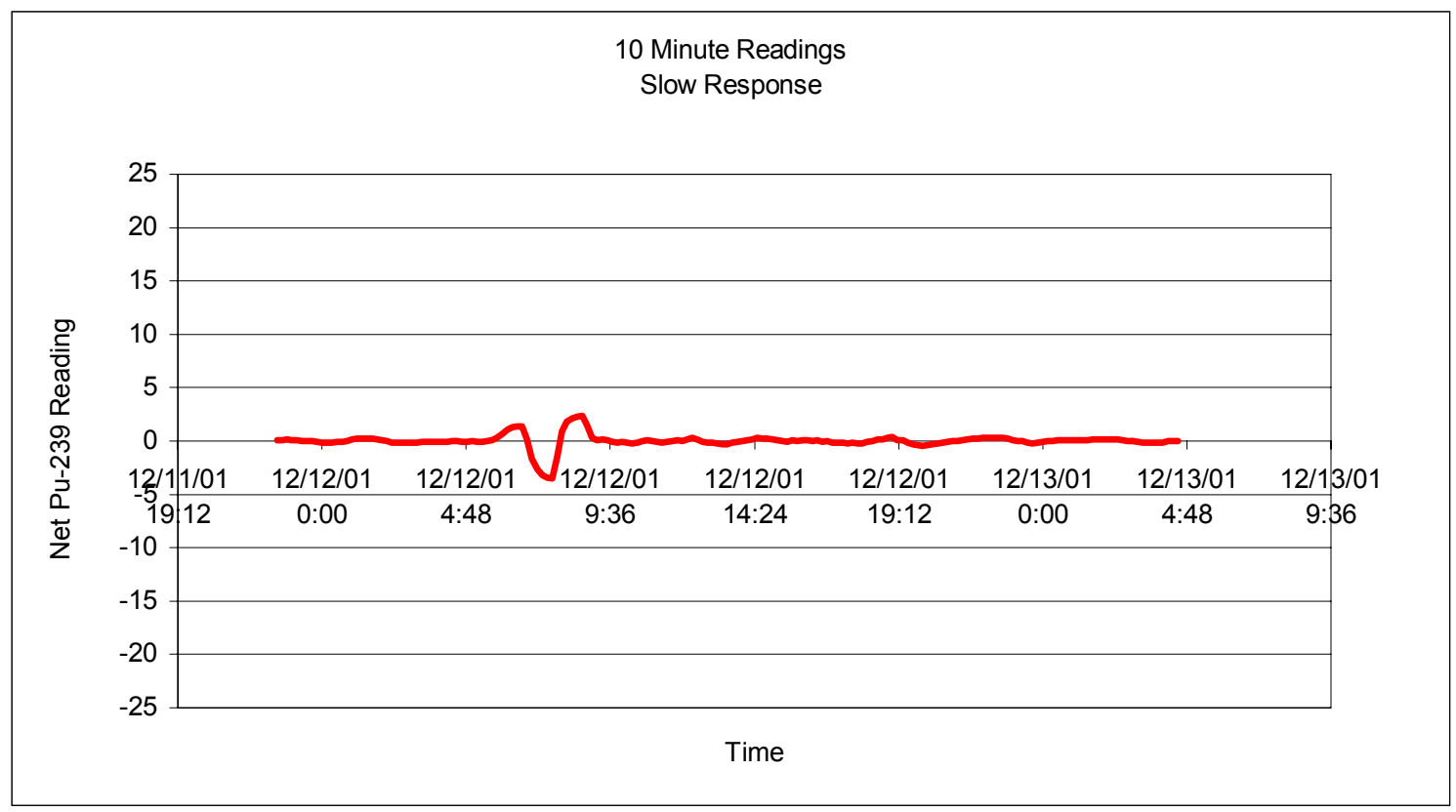

Figure 6. 10 Minute Readings - Slow Response 


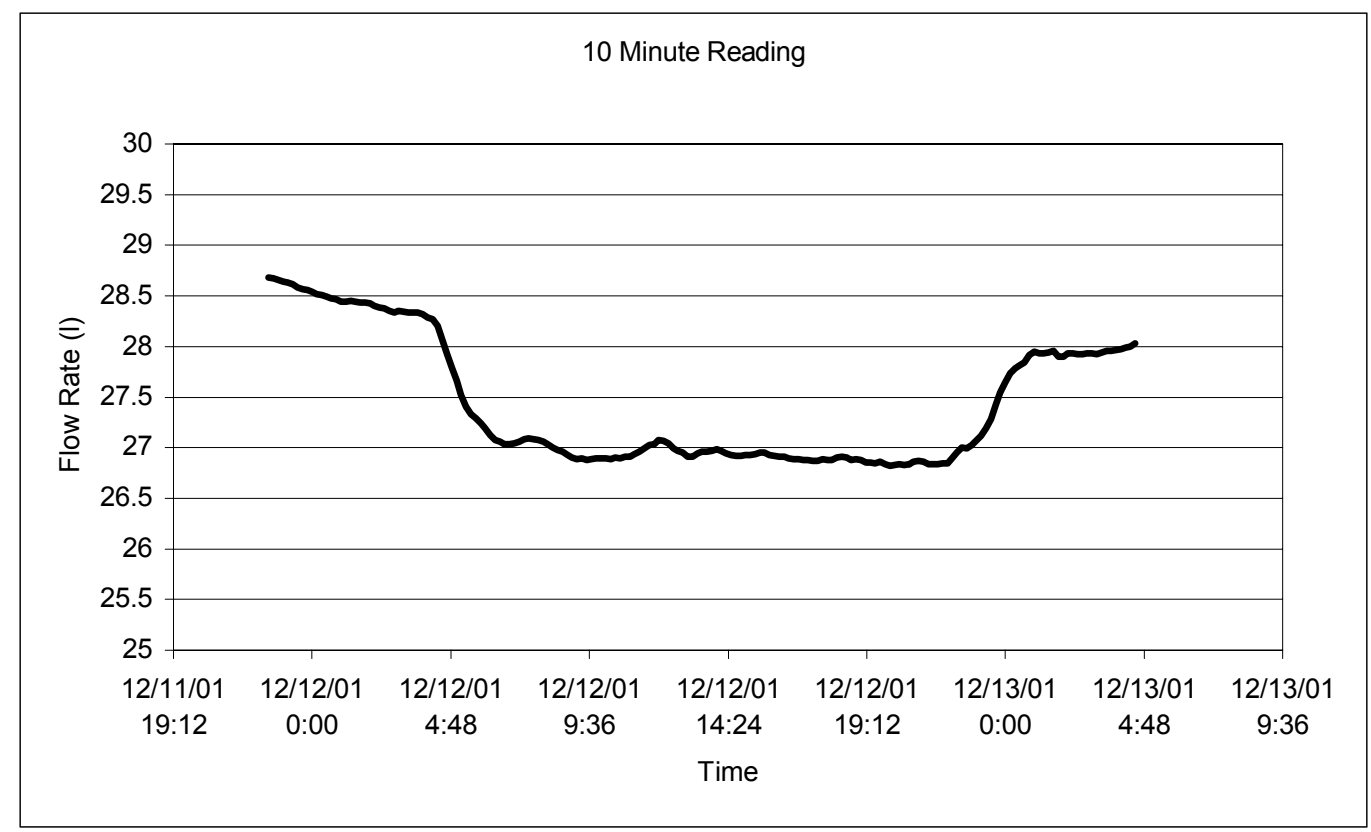

Figure 7. 10 Minute Readings

Figure 7 contains 10 -minute readings of the measured flow rate. The flow dropped during the 95\% exposure and recovered after returning to $40 \%$, although not completely.

No susceptibilities were observed except for the changes discussed when first exposed to the $95 \% \mathrm{RH}$ field. Flow rates were affected probably due to moisture loading of the filter. No alarms or failures were indicated for the duration of the test.

\section{Radio Frequency}

Test Parameters - Exposure to amplitude modulated (1 kHz at $80 \%)$ RF energy at 20 Volts/meter over a frequency from $20 \mathrm{MHz}$ to $1000 \mathrm{MHz}$.

\section{Results}

Susceptibilities were indicated as counts on the spectrum at $30 \mathrm{MHz}, 102,460,770$, and $895-960 \mathrm{MHz}$. Most of the counts were in the lower range of the spectrum but nonetheless caused curve fit problems that caused the unit to fail.

Additional analyses were performed to characterize the affects. Tests were performed with the unit entirely in the RF cell, with each main component in the cell (display or detector), and the entire unit with a braided shield over the interconnecting cable (detector to display). Figures 8 through 11 contain charts of the data obtained. Note the Y-axis on each chart. It has been fixed at $300 \mathrm{cps}$ even though some of the data was much greater than $300 \mathrm{cps}$. In addition, it must be stated that when susceptibility occurred, the unit took itself out of operation indicating poor curve fit. 


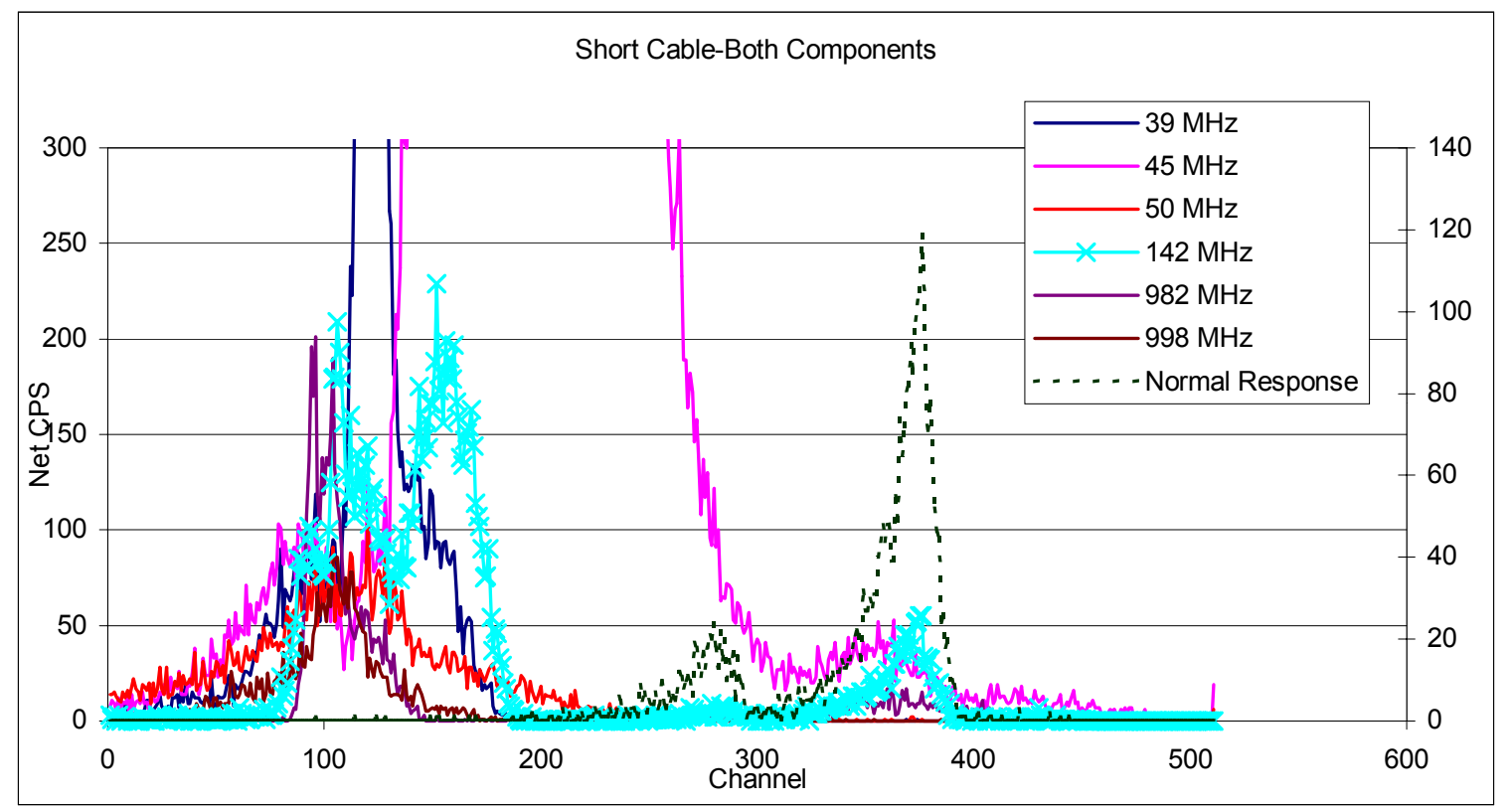

Figure 8. Short Cable, Both Components

Figure 8 shows the net cps readings taken with the entire unit in the GTEM (RF) cell. The table on the right indicates where susceptibilities were observed.

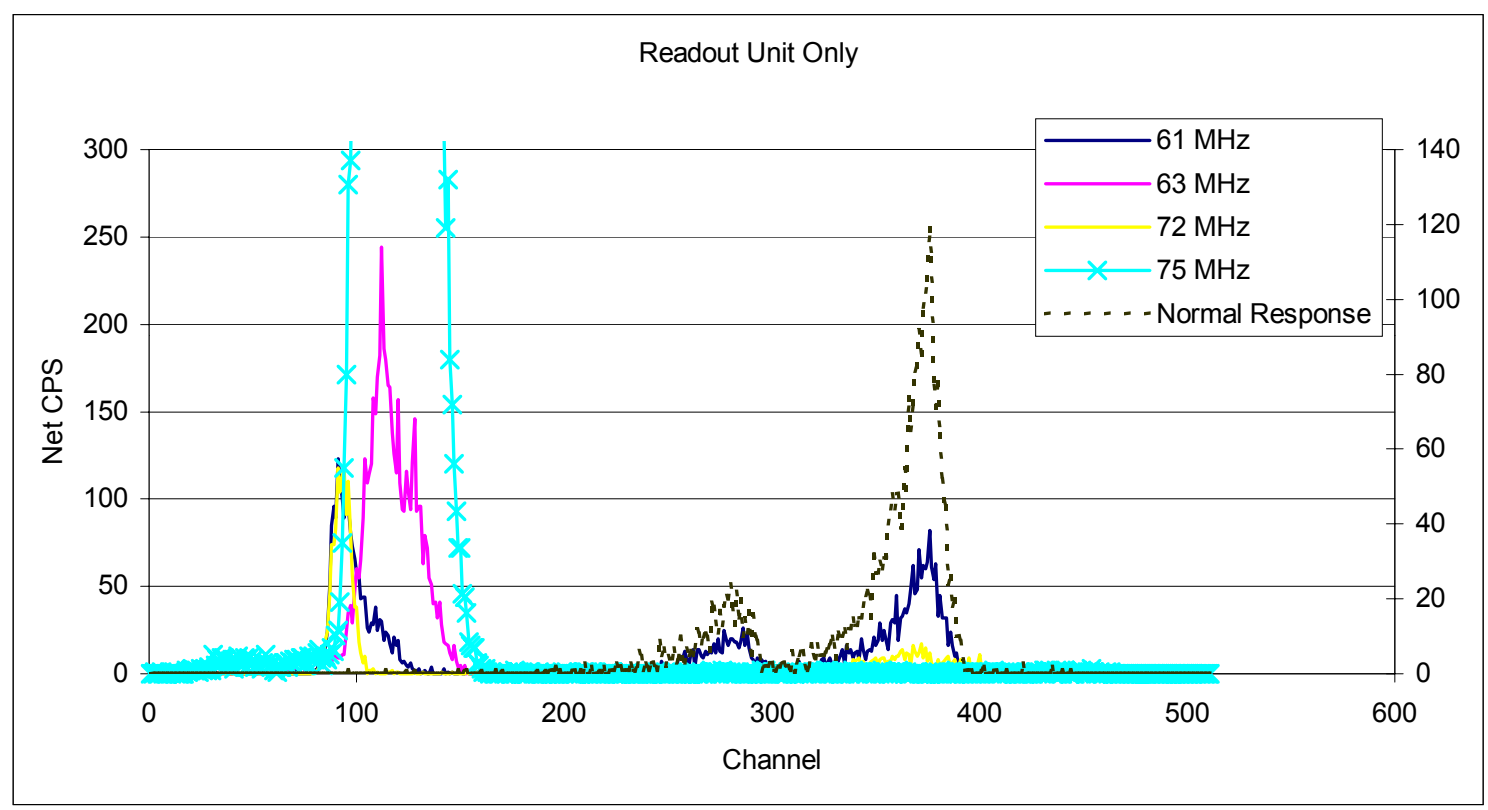

Figure 9. Readout Unit Only

Figure 9 presents the net cps readings obtained with the readout or display component in the RF cell only. 


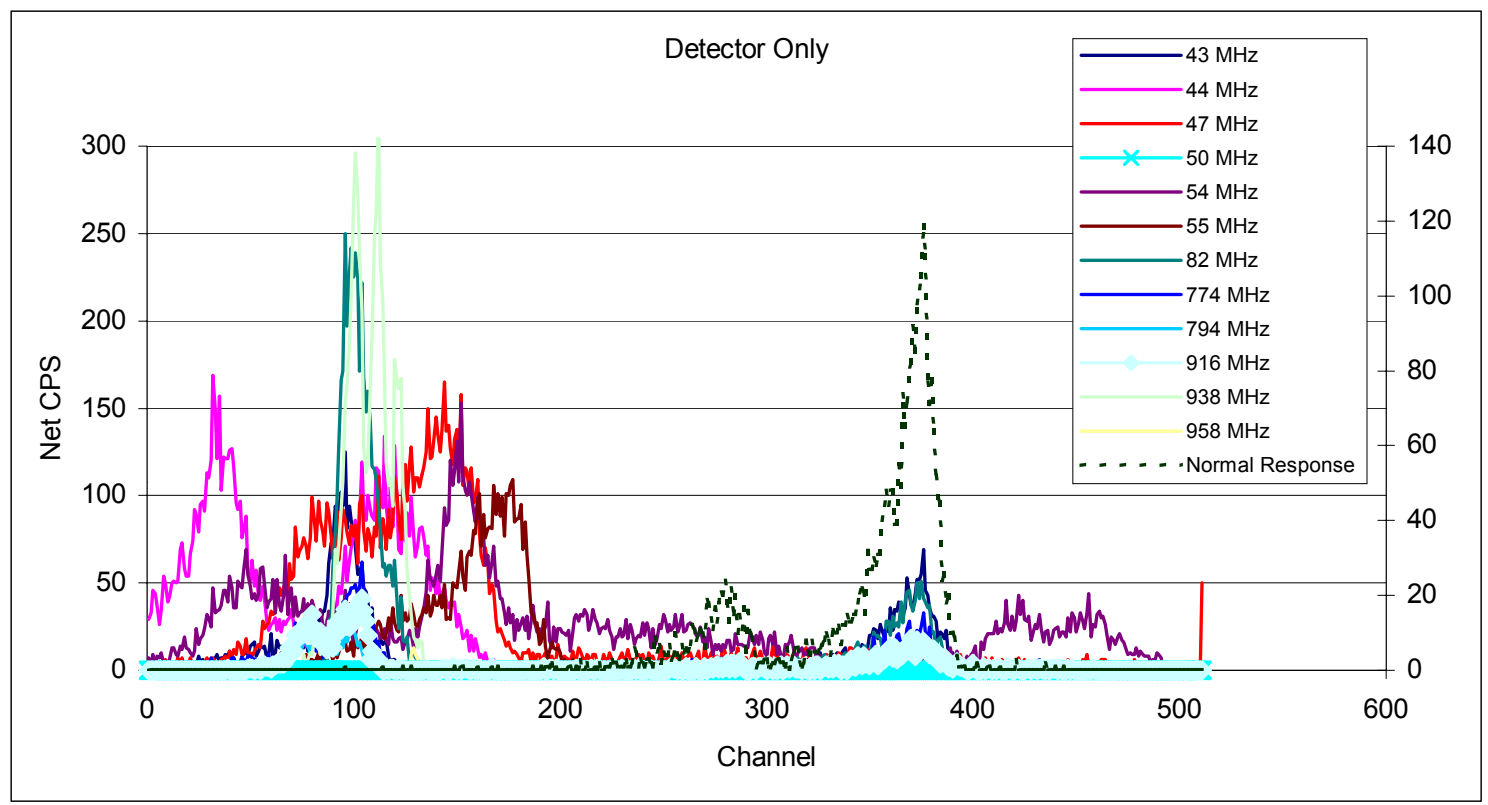

Figure 10. Detector Only

Figure 10 contains the net cps readings with the detector component in the RF cell only. Note the difference between the detector only and the display only results.

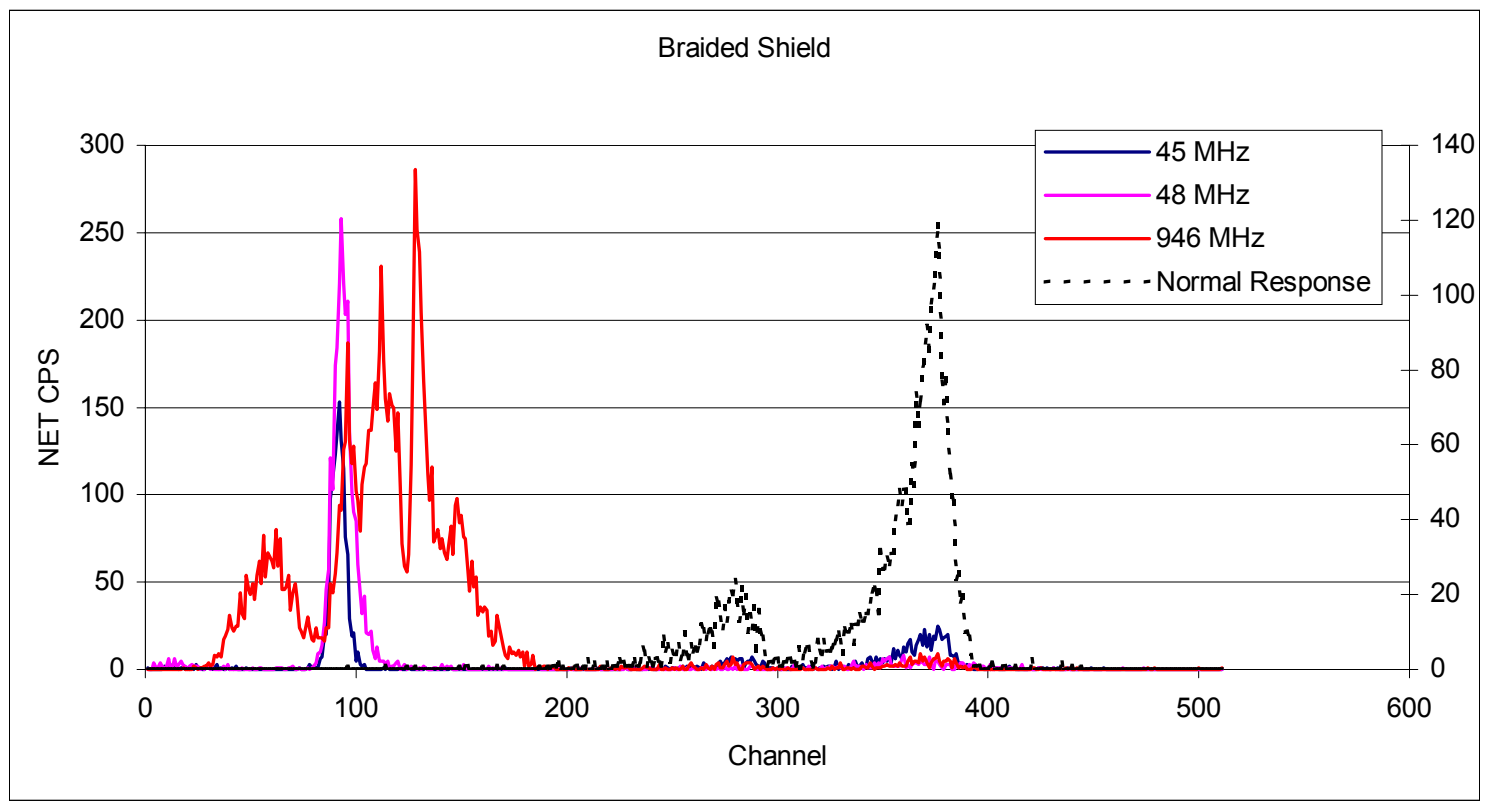

Figure 11. Braided Shield

Figure 11 shows the net cps readings with the entire unit in the RF cell, but now with the interconnecting cable covered with a braided shield. The intensity of the susceptibility was substantially reduced. 
Follow-Up Radio Frequency Testing

Based on observations made during initial RF testing, Eberline provided a replacement communications cable that was better shielded. The cable was replaced, and with the detector shield in place, the unit was re-tested. Table 1 lists the frequency bands, $\mathrm{MeV}$ ranges affected, and the observations made.

The primary concern for the users (LANL) of the Alpha 7L is from 406 and $420 \mathrm{MHz}$. The unit tested with the detector shield and shielded communications cable displayed susceptibilities from 402 to 406 and 412-414 MHz with the detector head-to-display unit cable coiled. During exposure, flow measurement was unaffected, the calculated $\mathrm{Pu}-239$ value was unaffected, and the status indication remained normal. Susceptibility was indicated by extra counts observed from approximately 2.5 to 3.0 $\mathrm{MeV}$. The test was performed at 20 Volts/meter. Further tests were performed with the cable uncoiled, as it should be set up during use. No susceptibilities were indicated over the test range of $350 \mathrm{MHz}$ to $500 \mathrm{MHz}$ at 20 Volts/meter. Susceptibilities remain, but much reduced, at the higher frequencies as shown on Table 1.

Table 1. Follow Up RF Test Results

\begin{tabular}{|l|l|l|}
\hline $\begin{array}{c}\text { Susceptibility } \\
\text { Band (MHz) }\end{array}$ & \multicolumn{1}{|c|}{ MeV } & Anomalies / Status \\
\hline $48-51$ & $2.5-3.3$ & Flow: OK; Pu-239 value: Unaffected; Status: Normal \\
\hline $63-69$ & $2.5-4.0$ & Flow: OK; Pu-239 value: Affected; Status: Poor curve fit \\
\hline $86-87$ & $2.5-3.5$ & Flow: OK; Pu-239 value: Unaffected; Status: Normal \\
\hline $133-137$ & $2.5-3.5$ & Flow: Low; Pu-239 value: Unaffected; Status: Flow Failure \\
\hline $145-148$ & $2.5-3.5$ & Flow: Low; Pu-239 value: Unaffected; Status: Flow Failure \\
\hline $253-270$ & $2.0-4.5$ & Flow: Low; Pu-239 value: Affected; Status: Fast Alarm \\
\hline $379-390$ & $1.0-3.5$ & Flow: OK; Pu-239 value: Affected; Status: Fast Alarm \\
\hline $390-395$ & $2.5-3.3$ & Flow: OK; Pu-239 value: Unaffected; Status: Normal \\
\hline $402-406$ & $2.5-3.0$ & Flow: OK; Pu-239 value: Unaffected; Status: Normal \\
\hline $412-414$ & $2.5-3.0$ & Flow: OK; Pu-239 value: Unaffected; Status: Normal \\
\hline $866-886$ & $2.0-2.8$ & Flow: OK; Pu-239 value: Unaffected; Status: Normal \\
\hline $886-908$ & $1.0-4.2$ & Flow: OK; Pu-239 value: Unaffected; Status: Normal \\
\hline $908-942$ & $2.2-3.3$ & Flow: OK; Pu-239 value: Unaffected; Status: Normal \\
\hline $942-948$ & $2.2-6.0$ & Flow: OK; Pu-239 value: Affected; Status: Poor curve fit \\
\hline $948-954$ & $.0-7.0+$ & Flow: OK; Pu-239 value: Affected; Status: Fast Alarm \\
\hline $954-962$ & $1.0-4.0$ & Flow: OK; Pu-239 value: Affected; Status: Fast Alarm \\
\hline $962-966$ & $2.5-2.8$ & Flow: OK; Pu-239 value: Unaffected; Status: Normal \\
\hline $992-1000$ & $1.0-3.3$ & Flow: OK; Pu-239 value: Unaffected; Status: Normal \\
\hline
\end{tabular}




\section{Conducted RF}

Test Parameters - Exposure to injected RF energy over a frequency range of $150 \mathrm{kHz}$ to $80 \mathrm{MHz}$ at an intensity of $140 \mathrm{~dB}(\mu \mathrm{V})$.

Results

The unit was tested using a coupling/decoupling network (CDN) by injecting RF transients onto the power line. No alarms or operational changes were observed during the exposure.

Figure 12 contains a chart showing the net cps response during the scan. The frequencies shown do not include all the frequencies used during the scan test. Although a minimal increase in the net cps value can be seen, this was most likely due to the normal fluctuations of the instrument from radon.

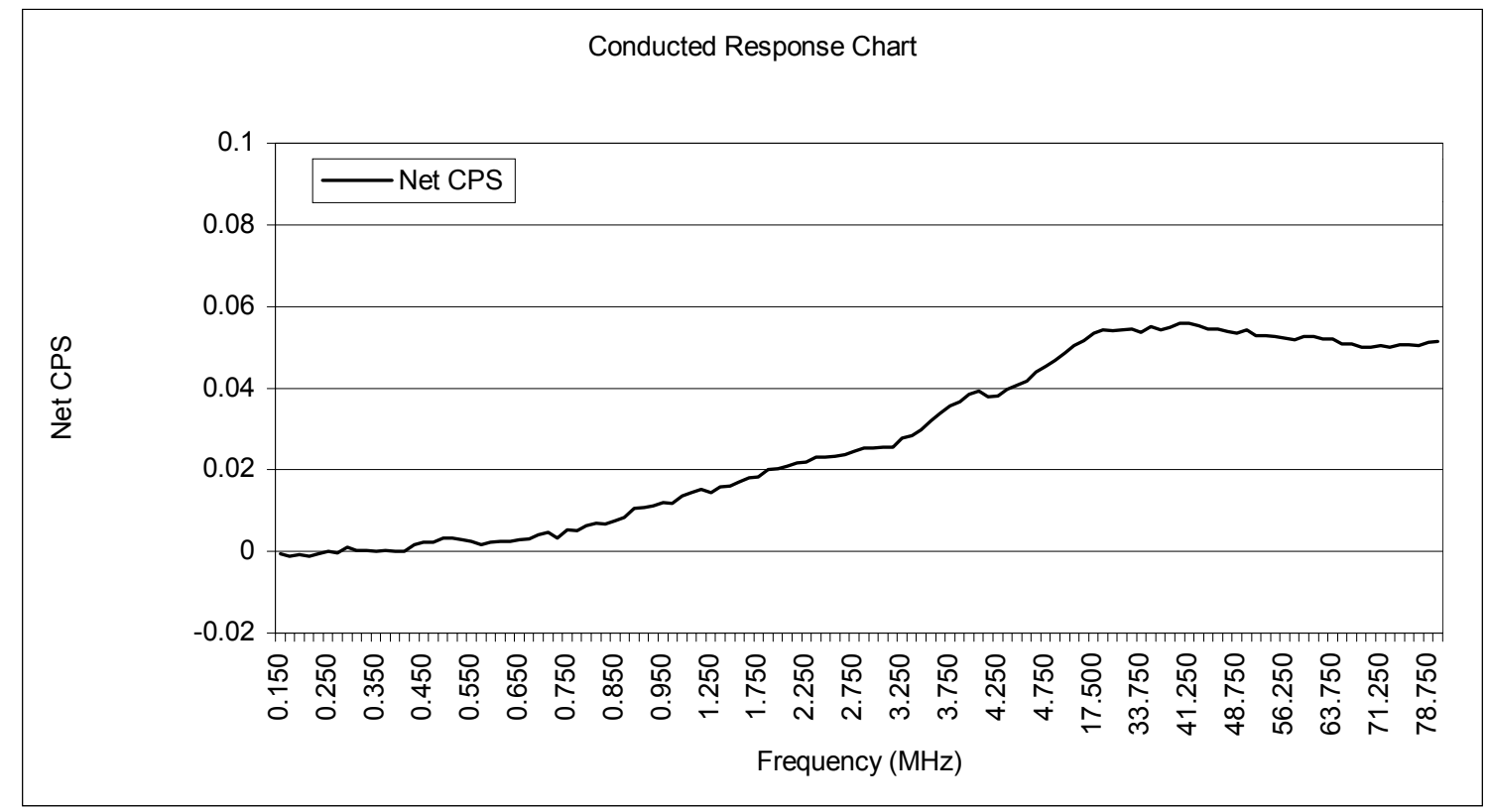

Figure 12. Conducted Response Chart

\section{Magnetic Fields}

Test Parameters - Exposure to 10 Gauss magnetic fields in two orientations.

Results

The Alpha 7L was exposed to a 10 gauss magnetic field in two orientations relative to the magnetic field lines. No alarms or operational changes were observed during the test. Figure 13 shows the net cps values taken during exposure for each magnetic field and orientation. 


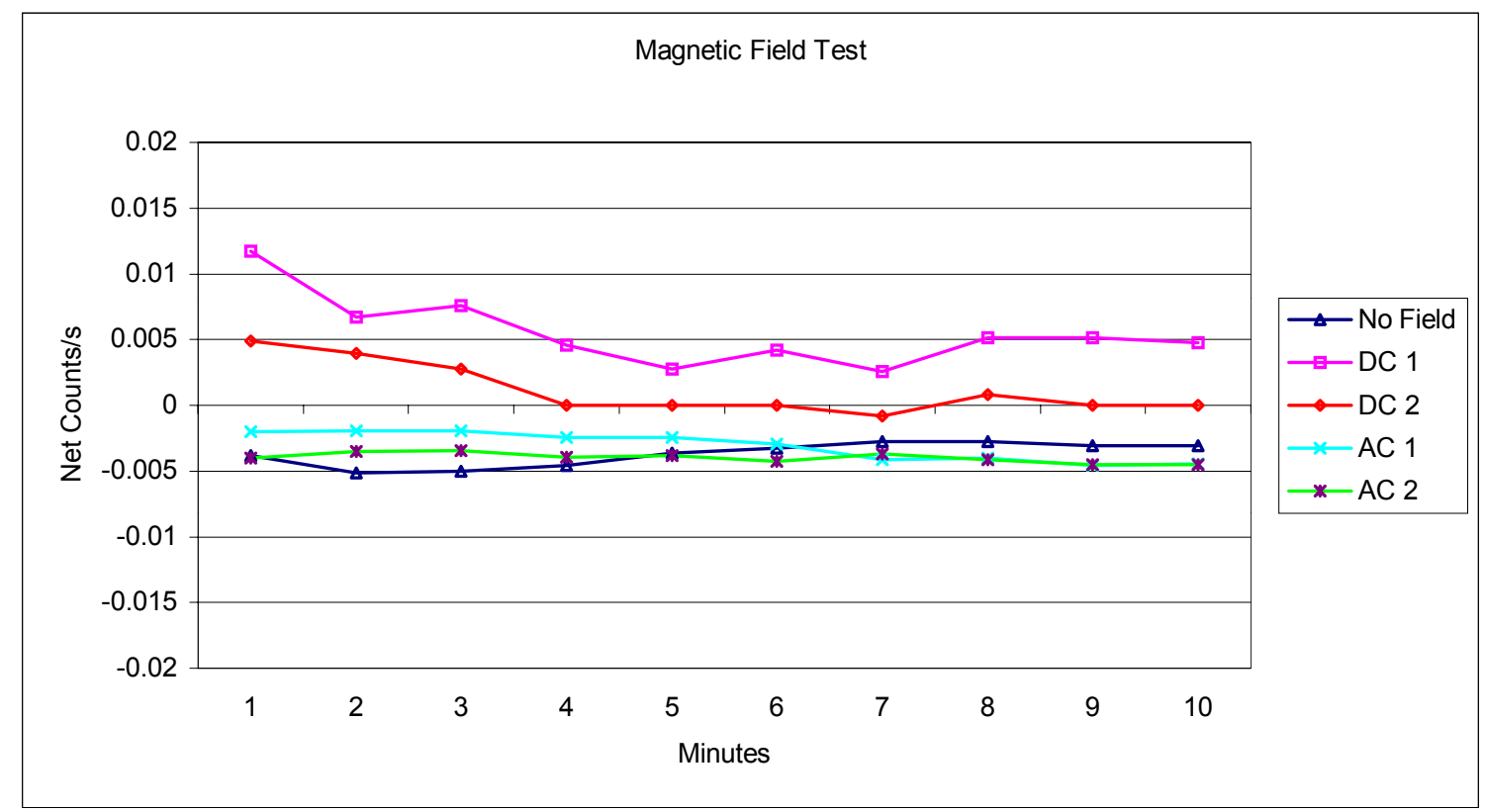

Figure 13. Magnetic Field Test

AC Line Power Variations

Test Parameters - Operations with line voltages from $103 \mathrm{~V}$ and $129 \mathrm{~V}$.

Results

No alarms or operational changes were observed during the test. Figure 14 contains the net cps values taken during exposure.

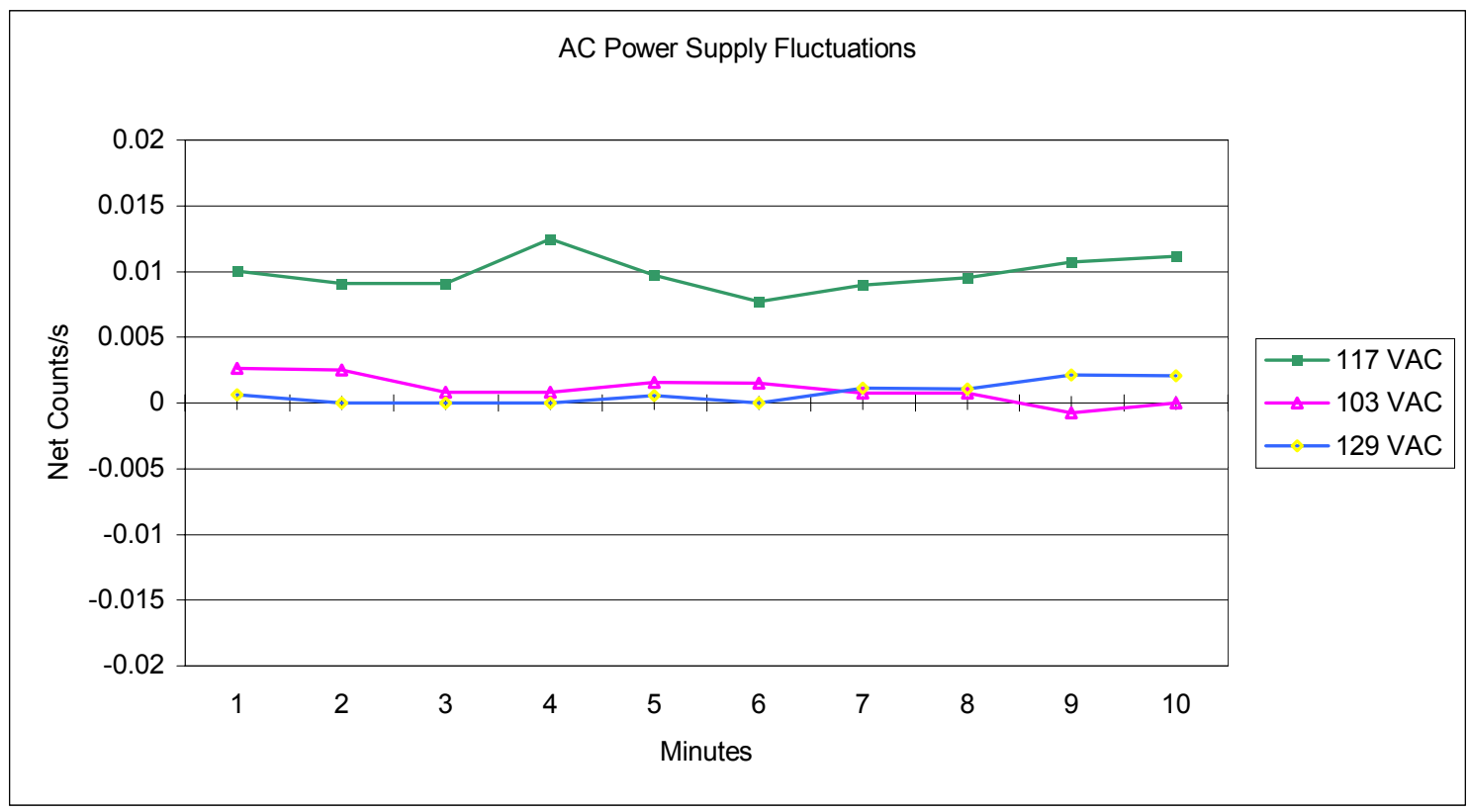

Figure 14. AC Power Supply Fluctuations 


\section{Surge Immunity}

Test Parameters - Exposure to surges over the power line.

\section{Results}

The Alpha 7L was exposed to two different pulse types, combination and ring wave. Pulses were applied to the main supply through the vendor-provided power cord. A series of fast DAC-h readings were taken prior to and after each exposure to determine if any post-test affects occurred. In addition, the unit was monitored during each exposure to document if alarms or other affects were indicated.

\section{Combination Wave}

The Alpha 7L was exposed to ten pulses consisting of a combination wave $(1.2 / 50 \mu \mathrm{s}-8 / 20 \mu \mathrm{s})$ at 2,000 volts peak amplitude. No post-test effects were indicated. The airflow rate, DAC-h readings, and alarms were monitored during the test with no anomalies indicated.

\section{Ring Wave}

The Alpha 7L was exposed to ten pulses consisting of a $100 \mathrm{kHz}$ ring at 2,000 volts peak amplitude. No post-test effects were indicated. The airflow rate, the DAC-h reading, and alarms were monitored during the test with no anomalies indicated.

\section{Interfering Ionizing Radiation}

Test Parameters - Exposure to gamma and neutron radiation fields.

Results

The Alpha 7 was tested to determine the affects of gamma or neutron radiation on the operations of the unit. The instrument was allowed 30 minutes to obtain a radon spectrum before being exposed to the interfering radiation. Exposure was to both components.

The gamma field used was from ${ }^{137} \mathrm{Cs}$ at an intensity of $1 \mathrm{rad} / \mathrm{hr}$. An unmoderated ${ }^{252} \mathrm{Cf}$ source was used to provide a neutron intensity of $1 \mathrm{rem} / \mathrm{hr}$.

Once the radon spectrum was obtained, the unit was exposed to the ionizing radiation field for two minutes. No abnormalities were observed from exposure to gamma. The neutron field caused the unit to go into alarm. The display unit was moved away from the field and the test was repeated. The results were the same with the detector only in the field. These results were expected.

\section{FOLLOW-UP TESTS}

Two additional production Alpha 7L units were provided by LANL for evaluation. Each unit included the recommended upgraded detector head to display unit communication cable, but didn't include the RF screen that is placed over the radial entry detector.

Tests performed included Temperature, Relative Humidity, and Radio Frequency.

\section{Temperature}

Test Parameters - Exposure to -10 to $+50{ }^{\circ} \mathrm{C}$

Results

No susceptibilities were indicated throughout the test. The calculated ${ }^{239} \mathrm{Pu}$ concentration level remained within $\pm 4 \mathrm{E}-3 \mathrm{pCi} /$ liter and the operating status remained "Normal." Figure 15 shows the ${ }^{239} \mathrm{Pu}$ concentration value and the actual temperature readings from the test. 


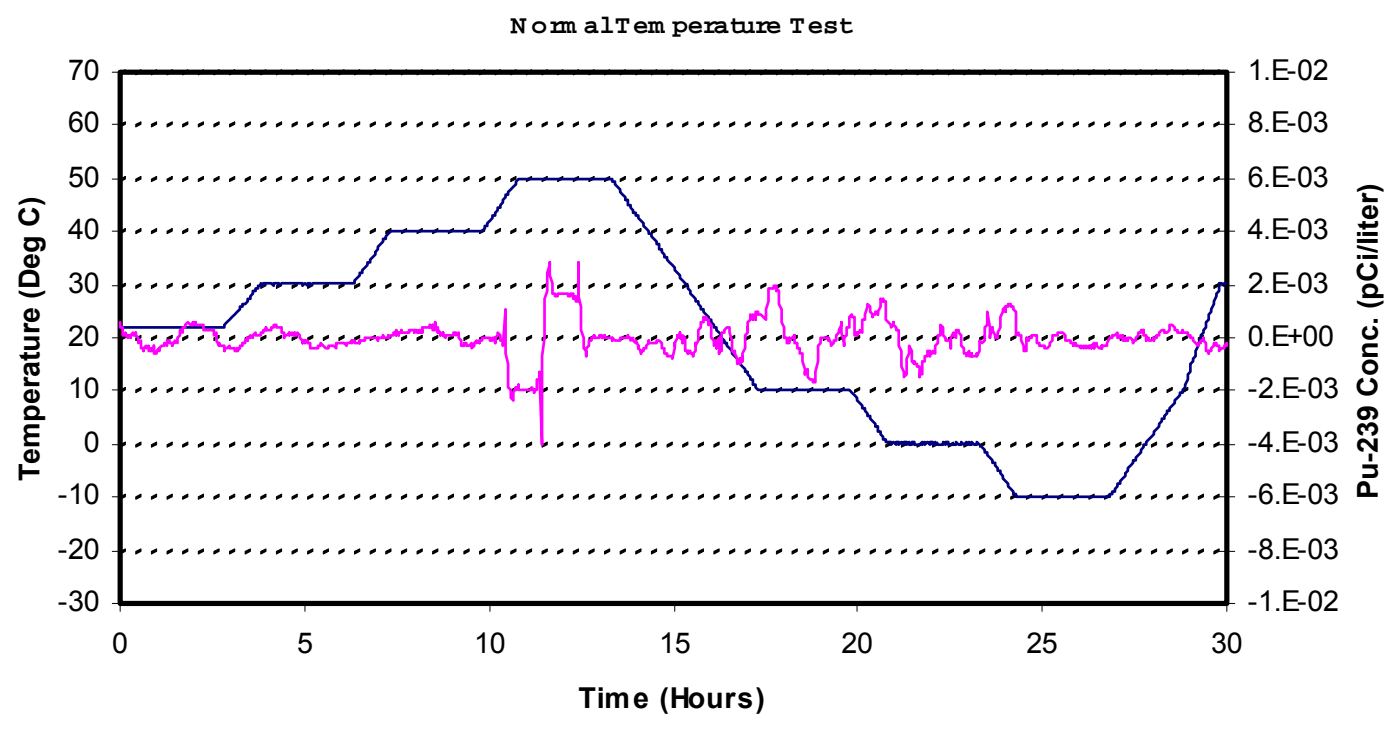

Figure 15. Temperature Test

Relative Humidity

Test Parameters - Exposure to $40 \%$ to $95 \%$ relative humidity (non-condensing) at a temperature of $30^{\circ} \mathrm{C}$ $\pm 2^{\circ} \mathrm{C}$

\section{Results}

No susceptibilities were indicated until near the end of the 24-hour exposure at 95\% RH. The unit became more erratic and the "Fast Concentration Alarm" activated. Figure 16 shows the ${ }^{239} \mathrm{Pu}$ concentration level and the actual RH conditions from the test.

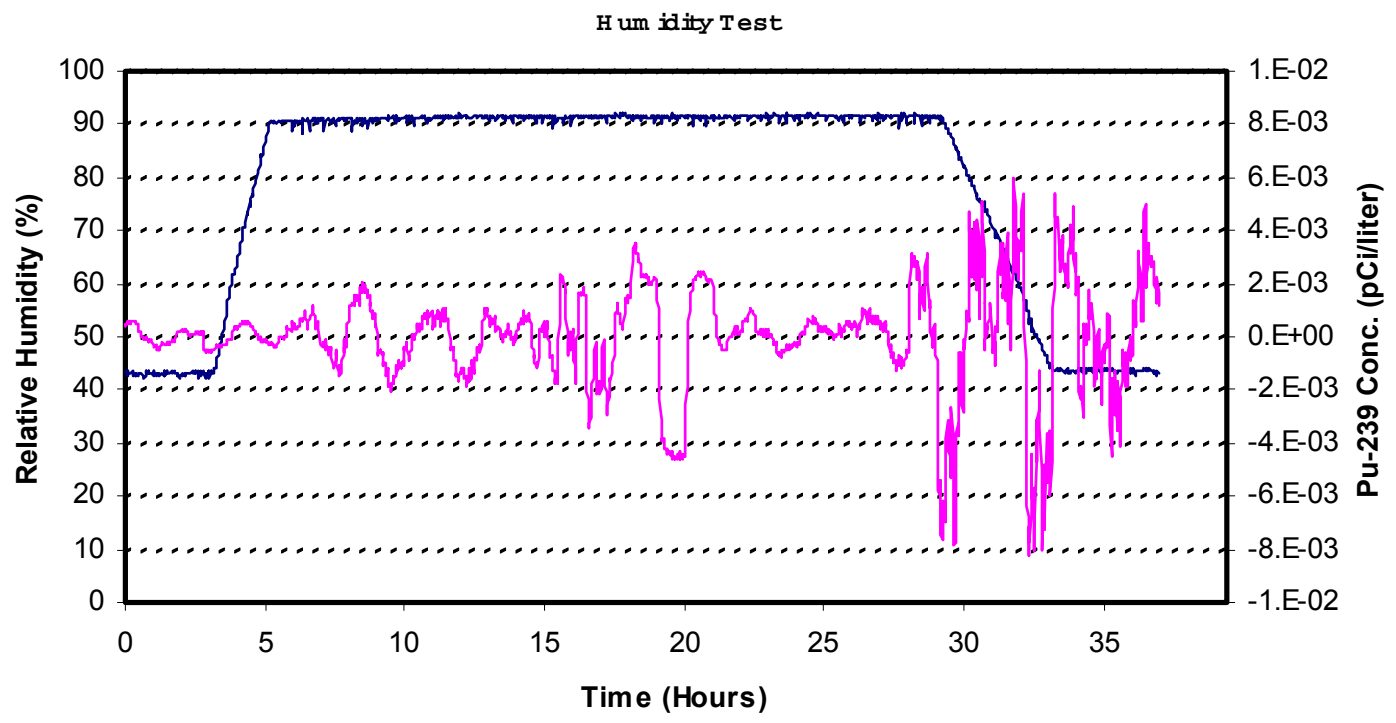

Figure 16. Humidity Test 
Radio Frequency

Test Parameters - Exposure to amplitude modulated (1 kHz at $80 \%) \mathrm{RF}$ energy at $20 \mathrm{Volts} /$ meter over a frequency range from $25 \mathrm{MHz}$ to $1000 \mathrm{MHz}$.

Results

Susceptibilities were indicated at different frequencies throughout the test. Most of the susceptibilities were indicated as counts on the lower energy range of the spectrum and didn't affect the monitor's ability to determine the ${ }^{239} \mathrm{Pu}$ concentration level. Frequency ranges that caused response affects are shown in the following table.

Table 2. Frequency Ranges

\begin{tabular}{|c|c|c|}
\hline $\begin{array}{l}\text { Susceptibility } \\
\text { Band (MHz) }\end{array}$ & $\underline{\mathrm{MeV}}$ & Anomalies / Status \\
\hline $42-44.6$ & o Spectrum & Flow:?; Pu-239 value: Affected; Status: MCA Failure \\
\hline $5.3-47.3$ & $2.0-7.0$ & Flow: OK; Pu-239 value: Affected; Status: Fast Dose \\
\hline $53-56$ & $2.0-10$ & Flow: OK; Pu-239 value: Affected; Status: Normal \\
\hline $56-62$ & o Spectrum & Flow:?; Pu-239 value: Affected; Status: MCA Failure \\
\hline $342-362$ & $1.0-10$ & Flow: OK; Pu-239 value: Affected; Status: Fast Dose \\
\hline $720-750$ & $1.5-6.0$ & Flow: OK; Pu-239 value: Affected; Status: Normal \\
\hline
\end{tabular}

\section{SUMMARY}

Although various susceptibilities were observed during the performance of this evaluation, the Eberline Alpha 7L appeared to operate well during most environmental conditions. The manufacturer provided excellent support when problems needed to be addressed, with those primarily involving susceptibility to radio frequency fields. Recommendations were made to the user organization with regards to cable placement to also reduce the susceptibility of the monitor to RF. It is recommended that some level of routine testing be performed to ensure that no degradation of components occurs during the operating life of the equipment that could go unnoticed by the user. It must be noted that all susceptibilities were indicated as operational status changes by the monitor. 


\section{INTERNAL DISTRIBUTION}

1. P. J. Chiaro, Jr.

2. J. E. Dixon

3. E. C. Fox

4. F. R. Gibson

5. D. C. Gregory

6. J. E. Hardy

7. J. B. Hunt

8. K. L. Reaves

9. A. A. Shourbaji

10. ORNL Laboratory Records-RC

11. Laboratory Records

\section{EXTERNAL DISTRIBUTION}

David Wannigman

MS E503, ESH-1

Los Alamos National Laboratory

Los Alamos, NM 87545 